\title{
Ecclesia Martyrum versus permixta Ecclesia: notas histórico-conceituais a partir da eclesiologia antidonatista de Agostinho de Hipona
}

\author{
Tiago de Fraga Gomes* \\ Darlan Paulo Lorenzetti**
}

\section{Resumo}

O presente artigo aborda o pensamento eclesiológico de Agostinho de Hipona, sobretudo, nos escritos antidonatistas, mediante três seções: o donatismo como fenômeno histórico, seu contexto epocal, as razões de sua gênese enquanto acontecimento e suas linhas teológico-doutrinais; as formulações por meio das quais Agostinho discutiu a inconsistência teórica da tese cismática donatista da Ecclesia Martyrum, propondo o paradigma inclusivo da permixta Ecclesia como uma espécie de eclesiologia de comunbão que permite que santos e pecadores convivam na mesma Igreja; por fim, tomando o ideal de comunhão como pressuposto basilar, se adentra no núcleo duro da reflexão agostiniana quanto à Igreja, Corpo de Cristo.

Palavras-chave: Agostinho; Donatismo; Igreja; Corpo de Cristo; Comunhão.

* http://orcid.org/0000-0001-5437-2318. URL http://orcid.org/0000-0001-5437-2318. Pontifícia Universidade Católica do Rio Grande do Sul. Professor do Programa de PósGraduação em Teologia da Pontifícia Universidade Católica do Rio Grande do Sul (PUCRS) e Perito da Comissão para a Doutrina da Fé da Conferência Nacional dos Bispos do Brasil (CNBB). Doutor em Teologia pela Pontifícia Universidade Católica do Rio Grande do Sul (PUCRS), com estágio pela Ruhr-Universität Bochum (RUB, Alemanha).

** https://orcid.org/0000-0003-0155-6214. URL https://orcid.org/0000-0003-0155-6214. Pontifícia Universidade Católica do Rio Grande do Sul. Doutorando em Filosofia pela Pontifícia Universidade Católica do Rio Grande do Sul (PUCRS). Bolsista da Coordenação de Aperfeiçoamento de Pessoal de Nível Superior (CAPES). 


\title{
Ecclesia Martyrum versus permixta Ecclesia: historical- conceptual notes from the anti-Donatist ecclesiology of Augustine of Hippo
}

\begin{abstract}
This article approaches the ecclesiological thought of Augustine of Hippo, above all, in the anti-Donatist writings, through three sections: Donatism as a historical phenomenon, its epochal context, the reasons for its genesis as an event and its theological-doctrinal lines; the formulations through which Augustine discussed the theoretical inconsistency of the Donatist schismatic thesis of Ecclesia Martyrum, proposing the inclusive paradigm of the permixta Ecclesia as a kind of ecclesiology of communion that allows saints and sinners to coexist in the same Church; finally, taking the ideal of communion as a basic presupposition, one enters into the hard core of Augustinian reflection on the Church, Body of Christ.
\end{abstract}

Keywords: Augustine; Donatism; Church; Body of Christ; Communion.

\section{Ecclesia Martyrum versus permixta Ecclesia: apuntes histórico-conceptuales de la eclesiología anti-donatista de Agustín de Hipona}

\section{Resumen}

Este artículo aborda el pensamiento eclesiológico de Agustín de Hipona, sobre todo, en los escritos anti-donatistas, a través de tres apartados: el donatismo como fenómeno histórico, su contexto epocal, las razones de su génesis como acontecimiento y sus líneas teológico-doctrinales; las formulaciones a través de las cuales Agustín discutió la inconsistencia teórica de la tesis cismática donatista de Ecclesia Martyrum, proponiendo el paradigma inclusivo de la permixta Ecclesia como una especie de eclesiología de comunión que permite a santos y pecadores convivir en una misma Iglesia; finalmente, tomando el ideal de comunión como presupuesto básico, se entra en el núcleo duro de la reflexión agustiniana sobre la Iglesia, Cuerpo de Cristo.

Palabras clave: Agustín; Donatismo; Iglesia; Cuerpo de Cristo; Comunicación.

\section{Introdução}

$\mathrm{Na}$ consociação das mentes que em larga escala colaboraram para a performance da cultura e do universo simbólico dos quais somos receptores no terceiro milênio da era cristã, Agostinho de Hipona (354-430), ocupa, deveras, um espaço privilegiado. Aqueles que lhe atribuem a alcunha de Mestre do Ocidente, muito possivelmente o fazem tendo em vista o decisivo impacto deste personagem para o desenvolvimento de aspectos basilares que até hoje firmemente constituem o ethos cristão. Neste sentido, revisitar Agostinho é sempre oportuno no que diz respeito ao resgate daquela 
a partir da eclesiologia antidonatista de Agostinho de Hipona

sabedoria que se configura como fonte perene e revitalizadora da Tradição. Compreender a natureza e o lugar do cristianismo e, em particular, da Igreja no mundo contemporâneo e pós-moderno, põe-se, não há dúvida, como tarefa íngreme e desafiadora a todos quantos ousem sobre ela debruçar-se. Por conseguinte, esta é uma reflexão que invariavelmente conduz-nos para questões verdadeiramente fulcrais que, em última análise, dizem respeito ao próprio ser da Igreja enquanto tal, ou seja, a Igreja em seu estatuto ontológico mais fundamental. É precisamente neste quesito que Agostinho, como tantas outras fontes inerentes à Tradição cristã, dispõem-se como auxílio sempre profícuo ao espírito reflexivo dos homens e mulheres de todas as eras.

No tocante às questões de natureza estritamente eclesiológica, sua obra é extremamente densa e, por isso, capaz de muito significar. Conforme demonstraremos neste breve excurso elucubrativo, a eclesiologia agostiniana gravita em torno de um ponto nevrálgico: a polêmica com o donatismo. Desse ponto de vista, este segmento do pensamento de Agostinho guarda certas similitudes com outros núcleos temáticos. Como se sabe, a maior parte de seus escritos sobre o mal, a liberdade, a vontade e a criação, articulam-se em torno do embate com o maniqueísmo. Já no que se refere aos textos sobre a graça e o pecado, o hiponense estabelece ardorosa confrontação com o pelagianismo. Outrossim, em se tratando da representação conceitual e esquemática referente a uma eclesiologia, se tem novamente uma chave de leitura eminentemente polemista. Deste panorama extrai-se uma conclusão, em nosso juízo, bastante razoada: a adequada compreensão dos diversos contornos da eclesiologia agostiniana impõe a qualquer estudioso um movimento impreterível, isto é, elucidar de modo suficiente os pressupostos elementares do donatismo enquanto doutrina.

Quanto ao esquema metodológico deste trabalho, se tomará como referência o itinerário proposto por Charles Lamartine em sua obra A Igreja Corpo de Cristo (2021), estruturada em três grandes blocos: 1) O donatismo na história; 2) Agostinho e a questão donatista; 3) A Igreja Corpo de Cristo. Assim, numa primeira seção, ainda que suscintamente, se reconstituirá as linhas gerais do contexto histórico e religioso pelos quais o donatismo pode ser entendido em seu surgimento e desenvolvimento. Tendo emergido no norte da África nos primeiros anos do século IV, o donatismo demonstrou desde seus primórdios, exacerbada preocupação pela pureza moral e pela santidade, quase uma obsessão em erigir uma Ecclesia Martyrum, isto é, uma Igreja que fosse apenas para os mártires e santos. A afirmação de seus 


\section{Tiago de Fraga Gomes}

Darlan Paulo Lorenzetti

princípios teológicos e doutrinais teve como desdobramento inevitável a cizânia no coração da Igreja.

$\mathrm{Na}$ segunda seção se abordará mais atentamente às formulações eclesiológicas de Agostinho. O que será feito com base, sobretudo, em escritos nos quais estão deflagrados os pressupostos elementares pelos quais Agostinho presbítero e, depois, bispo de Hipona, intentou oferecer refutação àquelas ideias, em sua ótica, absurdas e nefastas, defendidas pelos donatistas. Ideias estas que eram por ele consideradas altamente nocivas devido à sua potência cismática, isto é, pela sua capacidade de gerar dissensão na Igreja de Cristo. Em resposta ao separatismo puritano de tal seita, Agostinho fundamentou um conceito de Igreja em absoluto distinto daquele defendido por seus adversários. Se o donatismo apregoou a existência de uma Igreja onde somente os detentores da máxima pureza e perfeição pudessem tomar parte, o doutor de Hipona formulou algo como uma permixta Ecclesia, ou seja, uma Igreja mista, onde santos e pecadores pudessem assentar-se e caminhar lado a lado até que sobrevenha o juízo final, quando enfim "o joio será separado do trigo" (Mt 13, 40).

Esta configuração em que, em última análise, todos são acolhidos, em que a Cidade de Deus e a Cidade dos homens coexistem em meio à Igreja terrena e peregrina neste mundo, já parece sugerir que a eclesiologia agostiniana modula uma eclesiologia de comunhão. Esta noção será desvelada ao longo da terceira e última seção, sobretudo a partir da meditação acerca da expressão Igreja, Corpo de Cristo. Ao contrário do que acreditavam os donatistas, Agostinho sustenta que a Igreja, enquanto entidade ontológica, não se esgota em sua realidade histórica, visível e contingente. $\mathrm{Na}$ verdade, ela encontra o fundamento do seu ser naquela realidade outra, inscrita no horizonte escatológico da eternidade e da perfeita comunhão com Deus, condição da qual já goza a Igreja invisível e triunfante - com o Concílio Vaticano II, a tradicional classificação Igreja peregrina, padecente e triunfante é substituída por Igreja terrestre e Igreja celeste, unida pelos vínculos da comunhão dos santos -; esta Igreja, por sua vez, já se vê intimamente atrelada ao Cristo, ao modo como o corpo une-se à cabeça, formando com Ele o totus Christus. Enquanto caminha neste mundo guiada por esta teleologia eônica, a Igreja através de sua missão e pastoreio, faz-se sacramento de Cristo, instrumento da perenidade de sua encarnação e, portanto, sinal visível de sua presença no mundo. 
a partir da eclesiologia antidonatista de Agostinho de Hipona

A Igreja cismática: elementos gerais da eclesiologia donatista

Traçar um percurso de reconstrução reflexivo-conceitual em torno de um fenômeno histórico como o donatismo, que desde seu advento temporal nos antecede em mais de dezessete séculos, põe-se como uma tarefa cujos limites são evidentes quanto à precisão. Já de início, é importante atentar à uma advertência feita pela teóloga norte-americana Maureen A. Tilley: Todo historiador que se compromete em desvendar os diversos meandros do movimento donatista enfrentará considerável dificuldade no que toca ao acesso às fontes bibliográficas primárias, dada a escassez das mesmas. Infelizmente, afirma Tilley, mantém-se preservada "uma quantidade muito limitada de dados sobre a controvérsia donatista, além daqueles gerados pelos próprios donatistas" (1996, p. 22). Nesse sentido, Agostinho desempenha um papel muito relevante também do ponto de vista historiográfico, ao passo que a obra do mesmo se constitui como material referencial para aquilo que hodiernamente é possível conhecer acerca do donatismo. Como bem acentua Tilley, "na maioria dos casos, esse material vem de seus oponentes católicos, Optato de Milevi e Agostinho de Hipona, que estavam a uma geração ou mais de distância das fases iniciais do movimento donatista" (1996, p. 22). Robert Markus ressalta tal panorama de escassez bibliográfica no verbete "Donato/Donatismo" da Augustine Through the Ages:

Há pouco material proveniente de fontes donatistas: algumas atas de mártires, identificadas como de origem donatista; alguns documentos de concílios donatistas do fim do século IV; obras de certos autores donatistas cuja maioria consiste de citações reportadas por seus adversários; uma parte da obra do teólogo donatista Ticônio; documentos transmitidos integralmente por Optato e, mais tarde, Agostinho. A legislação imperial e algum material epigráfico e arqueológico, amiúde de proveniência discutida, oferecem testemunhos úteis. Por fim, o essencial das atas da Conferência de Cartago de 411, e o resumo dela feito por Agostinho chegaram até nós (2018, p. 354).

Markus oferece uma breve e sintética definição, afirmando que "donatismo é o nome dado ao movimento cismático na Igreja norte-africana que nasceu com uma controversa eleição à sé de Cartago, entre 308 e 311" (2018, p. 354). Charles Lamartine recorda que o processo de gênese do donatismo enquanto potência cismática no contexto do Baixo Império Romano guarda relativa complexidade, sendo permitido lhe atribuir múltiplas causas, tanto de ordem geopolítica quanto social, econômica e cultural. Assim, 


\section{Tiago de Fraga Gomes}

Darlan Paulo Lorenzetti

tal evento contém simultaneamente implicações tanto de natureza teológica quanto política, o que o torna peculiar. Na compreensão de Lamartine, "quando se fala em donatismo não podemos entendê-lo como um movimento que aponta somente para uma disputa de caráter doutrinal-teológico, mas devemos levá-lo em conta, também, como sendo uma reação permeada por sentimentos de protesto e rebeldia” (2021, p. 17).

No âmbito das relações políticas, o movimento donatista configurouse como uma espécie de reação por parte dos habitantes das províncias do norte da África ao domínio romano e àquilo que, na ótica dos africanos, era compreendido como uma forma de poder abusivo. Tal sentimento de contrariedade ao ethos imposto pela dominação romana, foi historicamente potencializado a partir de um período muito específico: as sistemáticas e intensas perseguições movidas pelo imperador Diocleciano contra os cristãos entrementes os anos de 303 e 305. Em razão de sua severidade e implacabilidade, tal processo foi, ao longo da posteridade, nomeado como $a$ grande perseguição. $\mathrm{O}$ acossamento de Diocleciano às comunidades cristãs foi levado a cabo sobretudo através de uma série de editos. O primeiro deles teria sido promulgado nas antecedências da páscoa de 303.

Lamartine, amparado pela Historia Ecclesiatica de Eusébio de Cesareia oferece o seguinte relato a respeito das exigências e imperativos contidos neste primeiro edito. O mesmo "ordenava não somente levar ao chão as igrejas, mas destruir também as Escrituras com fogo, proclamando, ainda, que aqueles que ocupavam funções das casas de oração fossem privados de liberdade se persistissem na profissão da fé cristã. Conforme ele, esse foi o primeiro escrito contra os cristãos, mas logo depois apareceram outros" (2021, p. 19). Segundo Lamartine, o último dos editos de Dioclesiano teria promulgação em 304, e em seu texto dispunha "a todos, indistintamente, clérigos ou fiéis leigos, a obrigação de oferecer sacrifícios aos deuses pagãos e exercer um ritualismo de incensação (thurificatio) para as divindades imperiais" (2021, p. 19). Lamartine ressalta que "a intenção do imperador era aniquilar definitivamente o cristianismo, o que ajudou a esclarecer o motivo do seu comportamento terrivelmente duro e das atrocidades adversas cometidas contra a religião cristã" (2021, p. 19).

Os cristãos do norte da África comportaram-se de modo múltiplo e variado face os horrores decorrentes da perseguição imperial. Muitos aceitaram de bom grado a possibilidade do martírio, enxergando neste um ato de heroísmo e suprema fidelidade aos princípios da fé em Cristo. Conforme 
Lamartine, sobre alguns se pode inclusive dizer que "assumiram a postura fanática de tornar-se mártir a qualquer custo" (2021, p. 19). Boa parte, contudo, capitulando à pressão do Império, acabou optando pela entrega dos objetos sagrados. Muitos, incluindo padres e bispos, no afã de conservar a própria vida, acabaram até se refugiando em locais secretos.

Cessadas as perseguições, a interpretação dos acontecimentos precedentes tornou-se um terreno de fervorosa disputa. Segundo Lamartine, nesse primeiro momento, já era possível reconhecer uma tensão em razão da existência de dois grupos distintos: de um lado, aqueles que apregoavam uma postura de misericórdia e acolhida por parte da Igreja aos lapsi ou traditores, isto é, aqueles que em meio ao cerco dos perseguidores em alguma medida hesitaram ou mesmo abandonaram sua fé; do outro, "um grupo de rigoristas que não aceitavam o retorno à Igreja daqueles que fugiram e se mostraram indignos cristãos (homens pecadores que não podiam fazer parte da assembleia dos 'perfeitos')" (2021, p. 19). Em pouco tempo, a radical aversão dos rigoristas aos traditores elevou a cizânia a tal condição que no seio do catolicismo norte-africano gerou-se algo muito similar a um movimento separatista. O estopim do cisma deu-se, precisamente, no ano de 311, em meio à conturbada eleição para o bispado de Cartago. Em De Haeresibus, Agostinho afirma que "os donatianos ou, melhor, donatistas são aqueles que inicialmente se separaram por causa de Ceciliano, que foi ordenado bispo da Igreja de Cartago contra sua vontade, acusando-o de crimes não comprovados e, acima de tudo, de ter sido ordenado por traditores das Sagradas Escrituras" (PL 42, haer. 69). Lamartine descreve com precisão os tumultuados acontecimentos que culminaram na configuração do chamado partido donatista, acontecimentos estes cujo conhecimento é indispensável no caminho de compreensão da eclesiologia antidonatista de Agostinho:

No ano de 311, com a morte de Mensúrio, bispo de Cartago, sede primaz da Igreja africana, foi eleito "com o sufrágio de todo o povo" - segundo o testemunho de Optato de Milevi - ao seu posto o diácono Ceciliano. Sua escolha não agradou aos extremistas rigoristas, e fez com que eles se voltassem contra a validade da sua consagração, questionando-a da causa da ausência dos bispos da Numídia, convidados por tradição para a eleição do bispo de Cartago, como também da presença, entre os consagrantes, de Félix de Aptungi, que era suspeito de ser um traditor. Discordando, pois, da eleição, reuniram-se em Cartago setenta bispos da Numídia, e concluíram por unanimidade, que não era válida a eleição de Ceciliano, consagrando-se, portanto, em seu lugar, um leitor de nome Maiorino. [...] A consagração de 
Maiorino representou o nascimento oficial do cisma, que logo mais seria chamado de donatista. [...] Concluída a eleição [...] os separatistas resolveram apelar ao imperador, pedindo o reconhecimento de Maiorino como legítimo titular da sede de Cartago. Porém em pouco tempo morreu o bispo cismático, sendo ele, desse modo sucedido por Donato de Casas Negras, que alguns preferiram chamar de "o Grande", por ter sido ele o ágil organizador e verdadeiro artífice do crescimento e da expansão da seita africana, que com os auspícios de suas ações, recebeu o nome de partido donatista (2021, p. 21-22).

Ao longo de todo o século IV, as constantes e persistentes investidas do partido donatista junto aos imperadores, no intuito de obter, por parte destes, o reconhecimento da legitimidade do movimento, não logrou êxito algum. Christian Tornau recorda que "desde 405, os donatistas foram submetidos às leis imperiais contra heresia e coagidos a reingressar na Igreja Católica por meios legais" (2020, p. 3). Há de se fazer menção a um breve período de exceção, entre os anos de 361 e 363, anos correspondentes ao governo do imperador Juliano (conhecido como Juliano, o apóstata), nos quais os donatistas gozaram de significativa simpatia por parte do mesmo. Agostinho, na Epistola 105, assim descreveu tal aproximação entre a seita e o poder imperial:

Juliano, o apóstata e inimigo de Cristo a pedido de seus seguidores, Rogaciano e Pôncio, concedeu a liberdade de perdição à seita de Donato além de restituir as basílicas aos hereges; ele estava, assim, convencido de que o Cristianismo desapareceria da terra se a unidade da Igreja, da qual se desprendeu, fosse eliminada e se fosse concedida liberdade às dissensões sacrílegas (PL 33, Ep. $105,2,9)$.

Todavia, os imperadores seguintes, (especialmente Teodósio que em 380 mediante o Edito de Tessalônica elevou o cristianismo ao status de religião oficial do Império) foram implacáveis em seu rechaço às pretensões da seita de Donato. Na medida em que o curso de institucionalização e consequente universalização da Igreja foi sendo consolidado, o donatismo em seu espírito separatista e localista foi, concomitantemente, se radicalizando. Para Marcos Roberto Piratelli, o donatismo põe-se como típico exemplo de resistência sectária e localizada ao ethos católico e, portanto, universalista da Igreja agora aliada ao Império. Conforme a religião cristã "foi se institucionalizando, configurando-se como Igreja 'universal', teve de enfrentar grupos de cristãos que se formaram como Igreja local [grupos que] preferiram não se incorporarem àquilo que ficou conhecida como Igreja católica” (2010, p. 1). 
a partir da eclesiologia antidonatista de Agostinho de Hipona

A natureza eclesiológica do donatismo é decisivamente performada pelo ímpeto separatista. Ao já ressaltado rigorismo inerente ao pensamento dos donatistas, subjaz a crença de que a única e verdadeira Igreja é a Ecclesia Martyrum, isto, a Igreja dos Mártires. Com efeito, para eles, a única Igreja digna do atributo verdadeira só poderia ser aquela parcela da Igreja norte-africana que não tornara a receber em seu seio os famigerados traditores. Assim, "os donatistas viam a si mesmos como legítimos sucessores daqueles que haviam permanecido inabaláveis durante a perseguição e afirmavam representar a tradição africana de uma Igreja cristã 'dos puros" (TORNAU, 2020, p. 3). A raiz dos erros donatistas reside, segundo Pedro Langa, precisamente em sua eclesiologia. A Igreja dos santos e puros encontrava-se circunspecta aos limites do norte da África, uma vez que os cristãos de todos os demais recantos do Império Romano haviam caído em perversão ao manifestarem misericórdia para com os traditores. É possível afirmar que "enquanto prova do catolicismo, o conceito de integridade era, para a seita, mais importante do que o de universalidade. Os únicos cristãos autênticos eram eles" (LANGA apud LAMARTINE, 2021, p. 31).

Tanto Agostinho, quanto Optato de Milevi, dois grandes oponentes do Donatismo no contexto dos séculos IV e V da era cristã, enxergaram no rigorismo excludente da seita, uma agressão a um dos atributos ontológicos da Igreja: a unidade. O primeiro, em seu tratado Contra os donatistas reage com indignação à pretensão do bispo Donato, cujo ministério vinha impregnado pela "audácia de separar o povo de Deus, para que aqueles que o seguiam não fossem mais chamados de cristãos, mas donatistas" (OPTATUS, 1997, p. 65). Agostinho, por sua vez, é ainda mais enfático em sua crítica. Em Sermones 198, Agostinho acusa os donatistas de praticamente haverem substituído o culto a Cristo pelo culto à personalidade de Donato:

Os donatistas colocam Donato no lugar de Cristo. Se eles ouvirem algum pagão depreciando a Cristo, eles provavelmente aguentam com mais paciência do que se eles ouvirem depreciar Donato. Eles são tão perversos em seu amor por Donato que o colocaram antes de Cristo. $\mathrm{Na}$ verdade, eles não apenas nada têm a dizer, mas também estão cientes de que nada têm a dizer. $\mathrm{Na}$ verdade, nada os mantém sob o nome de Cristo, senão o nome de Donato: eles foram pressionados a aderir ao nome de um homem, colocando-se contra Cristo. Por isso conceberam um ódio implacável também contra nós, porque gritamos a eles: "Não ponhas a tua esperança num homem, se não queres ser amaldiçoado” (PL 38, S. 198,45). 


\section{Tiago de Fraga Gomes}

Darlan Paulo Lorenzetti

O doutor de Hipona reconhece no donatismo algo como uma segunda perseguição à Igreja de Cristo. Diferentemente da primeira, que cuja gênese era encontrada na opressão exercida por elementos exteriores ao catolicismo, ou seja, a potestade imperial, a perseguição donatista ocorre de dentro para fora, corroendo as entranhas da instituição eclesial através da indução ao erro. Agostinho sustenta este entendimento de modo categórico nas Enarrationes in Psalmos: "A primeira perseguição à Igreja foi violenta, pois tentou com confisco de bens, tortura e homicídios, obrigar os cristãos ao sacrifício. Uma segunda fase de perseguição funciona mais por engano; é praticada em nossos dias por hereges e falsos irmãos de toda e qualquer espécie" (PL 36, En.Ps. 9,27). Prima facie poder-se-ia levantar diversas questões a respeito das razões pelas quais o donatismo, enquanto impulso cismático, persistiu ao longo de todo o século IV. Ora, se o ponto nevrálgico da contenda entre católicos e donatistas era a acolhida ou a condenação àqueles fiéis que em meio às perseguições abjuraram sua fé, uma vez que aquela geração de lapsis deixasse de existir, esvair-se-ia a fonte da controvérsia. Todavia, os donatistas, como lembra Jesse A. Hoover, levaram sua intransigência à últimas consequências. De acordo com Hoover, eles "tinham seus próprios nomes para seus oponentes. Eles eram traditores, 'entregadores' dos livros sagrados, cujos pecados sobreviveram nas ações assassinas de seus descendentes” (2018, p. 18).

O termo perseguição, como é de se supor, é também ele um signo em disputa. Se para Agostinho, Optato e demais prelados católicos, eram os donatistas que empreendiam perseguições à Igreja, estes últimos mantinham uma percepção inversa do cenário. Ao passo que a seita de Donato se entendia como detentora de toda pureza e santidade, aqueles com os quais estabelecia algum nível de confrontação eram, segundo sua ótica, com justiça temidos e odiados como os verdadeiros perseguidores. Contrariando uma leitura conjuntural tipicamente católica, o donatismo via-se não como agente de perseguições, mas como receptor das mesmas. Agostinho valeu-se desta alegação - no seu entender pitoresca e infundada - como um ensejo para reafirmar o primado da unidade como selo distintivo da vida eclesial católica. No Contra Gaudentium donatistarum episcopum, Agostinho chega a ironizar a acusação donatista a respeito de uma suposta perseguição movida pelos católicos: "Que perseguição vós sofreis, senão aquela que infligis a vós mesmos? O vosso perseguidor vos ama, enquanto a vossa fúria vos persegue: Ela deseja que fujais, isso vos impele a perecer" (PL 43, C.Gand. I 21,24). Para o hiponense, a real perseguição é o furor de dissensão pelo qual os donatistas 
eram guiados. Ao dizer que estes eram amados pelo seu suposto perseguidor, Agostinho sublinha o desejo e a expectativa dos irmãos do partido de Donato regressassem à comunhão da Igreja, realçando, deste modo, o selo da unidade pelo qual o catolicismo, em sua compreensão, distinguia-se.

Sendo assim, os reais perpetradores das perseguições não seriam os católicos, mas os próprios donatistas. Agostinho opera algo próximo a uma inversão argumentativa. Demonstra como "dor maior sofreram os católicos ao observarem que os dissidentes, mesmo possuindo os sacramentos de Cristo, viviam separados e rebelados contra a Igreja e a paz de Cristo" (FREITAS, 2013 , p. 8). O padecimento dos donatistas implicava em sofrimento por parte dos católicos, pois estes, em diversas oportunidades, acabavam vendo seus irmãos, em acesso de fanatismo, entregarem-se desesperadamente ao martírio como via de autorredenção. Esta eclesiologia alicerçada na crença de que a verdadeira Igreja de Cristo só poderia ser composta por santos, produziu inevitáveis reverberações na teologia sacramental do donatismo. Para o episcopado donatista, somente seriam válidos os sacramentos administrados por ministros santos. Ao contrário do que apregoavam os católicos, para os donatistas, no fundo, não é Cristo, mas a Igreja, por seus próprios atos e méritos, que desempenha o papel verdadeiro e imediato de sujeito da ação sacramental. No Contra Litteras Petiliani Donatistae de Agostinho, o supracitado contraste teológico-doutrinal torna-se cristalino no embate argumentativo travado entre Agostinho e Petiliano, bispo donatista de Constantina entre os anos de 395 e 412 :

Petiliano: Somos acusados de duplo batismo, justamente por aqueles que, sob o nome de batismo, mancharam a alma com uma lavagem falsa. É claro que, em face dessas obscenidades, toda sujeira é mais limpa do que aquela que sua água tocou e contaminou com pureza infiel.

Agostinho: Não somos contaminados pela nossa própria água e nem purificados pela vossa; a água do batismo, dada em nome do Pai e do Filho e do Espírito Santo, não é nem nossa nem vossa, mas daquele de quem João disse: "Aquele sobre o qual vereis descer o Espírito como pomba e sobre ele repousar, este é aquele que batiza no Espírito Santo" (PL 43, C. litt. Pet. II, 2, 4.5).

Ao redigir o De Haeresibus entre os anos de 428 e 430, portanto, já ao final de sua vida, Agostinho assinalou como ponto fulcral da controvérsia com o donatismo, o cisma decorrente das tensões relativas à eleição episcopal em 


\section{Tiago de Fraga Gomes \\ Darlan Paulo Lorenzetti}

Cartago no ano de 311. Do ponto de vista da disputa de caráter estritamente teológico, o bispo de Hipona faz menção à controvérsia em torno da prática donatista de rebatizar aqueles que outrora haviam recebido o sacramento pelas mãos de ministros, em seu juízo, indignos. "Também tiveram a audácia de rebatizar os católicos, e com isso deram maior confirmação aos hereges, pois toda a Igreja Católica decidiu não anular a comunhão do batismo, nem mesmo no caso dos hereges" (PL 42, haer. 69). Markus, todavia, atenta para o fato de que a questão em torno ao batismo encontra-se inscrita em um universo de contrariedades teológicas cuja amplitude e complexidade é muito maior do que pode-se, de início, supor. Tais contendas versam, em última análise, sobre o próprio estatuto ontológico do ser Igreja. Com efeito, é preciso reconhecer que "donatistas e católicos concordavam em muito, praticamente em tudo, dos elementos de sua crença tal qual professada no Credo. Seu desacordo se situa num nível mais profundo e irreconciliável: diz respeito à questão da natureza da Igreja" (MARKUS, 2018, p. 356).

À medida que se projeta o olhar em direção a tais sutilezas, se percebe que a polêmica antidonatista com a qual Agostinho se manteve ocupado por tantos anos, brota do entrechoque de duas tradições eclesiológicas radicalmente distintas: uma genuinamente norte-africana e que por sua vez, tinha na figura de Cipriano o seu referencial-mor; outra, estrangeira e transmarina, isto é, “importada de além-mar" (MARKUS, 2018, p. 356). Para Tilley, sob certo aspecto é adequado dizer que "o donatismo representa a herança ancestral do norte da África e Agostinho representa uma imposição itálica" (2011, p. 22). Em contraposição ao rigorismo e ao sectarismo inerentes à eclesiologia donatista, Agostinho elaborará um conceito de Igreja radicalmente diverso: a permixta Ecclesia (Igreja mista). Como será elucidado ao longo da seção subsequente, a mesma tem como substrato fundamental o horizonte de uma eclesiologia de comunhão, na qual santos e pecadores, puros e impuros, coexistem na mesma Igreja digna do atributo universal.

O visceral antagonismo estabelecido entre católicos e donatistas, isto é, entre cismáticos e ortodoxos, retrata o abalroamento de dois paradigmas eclesiológicos radicalmente opostos: o localismo africano versus o universalismo europeu, ou ainda, a Ecclesia Martyrum donatista frente à permixta Ecclesia do catolicismo. Agostinho, através de seus escritos antidonatistas esforçar-se-á em demonstrar a todos o quanto os rivais que lhe eram contemporâneos - a exemplo das facções da época de Cipriano eram intolerantes justamente por se autoconsiderarem cristãos mais puros 
a partir da eclesiologia antidonatista de Agostinho de Hipona

e, portanto, moralmente superiores. Em consonância com tal anseio crítico, o hiponense desvelará o fato que, segundo seu juízo, culminará na mais flagrante contradição do partido de Donato: "sob o pretexto de manter a santidade, eles [os donatistas] ignoraram a mais vitais das virtudes cristãs: o amor, a unidade e a paz” (CLINGER, 2016, p. 34).

\section{A Igreja mista: a resposta agostiniana ao donatismo}

No decorrer da seção anterior, se buscou deflagrar como a polêmica donatista se constituiu no âmbito eclesiológico, e como se deu o desenrolar inicial de uma acalorada disputa entre duas visões paradigmáticas antagônicas: uma sectária e outra universal. Pedro Langa ressalta esta prodigalidade de olhares simultâneos, segundo os quais, o donatismo pode ser compreendido enquanto acontecimento: "As origens deste complexo fenômeno religioso e mãe de todas as divisões, que foi o donatismo, respondem a múltiplas causas, próximas e remotas" (1988, p. 5). Entretanto, a toda esta complexidade de ordem geopolítica, etnográfica, social, econômica, cultural e política, subjaz uma noção unificadora, cuja palavra-chave é a romanização (LANGA, 1988, p. 5).

A ideia de romanização, por conseguinte, comportava em seu âmago um ideal de universalização. Em nível eclesiológico este ideal era expresso na comunhão universal das Igrejas particulares com a Igreja de Roma. O frade agostiniano Tarcisius Van Bavel, seguramente um dos mais proeminentes estudiosos da obra de Agostinho no século passado, sugere que ao formular seu conceito de permixta Ecclesia - Igreja mista - o doutor de Hipona parte de uma opção radical e definitiva por uma eclesiologia universalista. Em determinado momento, Agostinho teria se sentido obrigado a "decidir entre duas concepções de Igreja: a montanista-donatista e a de uma Igreja universal, católica; isto é, a de uma Igreja de puros e a de uma Igreja de pessoas boas e más, uma Igreja para a elite e uma Igreja para a massa" (BAVEL, 2018, p. 511). Como o intelecto humano é incapaz de em uma multidão de fiéis determinar quais serão salvos e quais serão condenados ao final - somente Deus o é -, optar por um modelo de Igreja mista pareceu, aos olhos de Agostinho, a deliberação mais prudente. Para Bavel, tal opção acaba tendo “implicações abrangentes e importantes" (2018, p. 511).

O enfrentamento intelectual ao donatismo foi uma empreitada com a qual Agostinho comprometeu-se por praticamente quarenta anos, ou seja, desde o início de seu presbiterado em Hipona no ano de 391, até o seu falecimento em 430. Lamartine divide o processo de envolvimento e 


\section{Tiago de Fraga Gomes \\ Darlan Paulo Lorenzetti}

atuação de Agostinho na polêmica com os donatistas em cinco momentos cronológicos distintos: 1) 391-395: período correspondente ao seu ministério presbiteral em Hipona. Sua prática nestes anos foi marcado pelo anseio de recondução dos cismáticos à comunhão eclesial, tendo se concentrado especialmente no estudo da Sagrada Escritura e da Tradição teológica norteafricana; 2) 396-400: anos iniciais de seu episcopado nos quais sua veia polemista e apologética aflorou intensamente, tendo ele produzido alguns dos mais importantes escritos de seu Corpus Antidonatista: Contra partem Donati, Contra Epistulam Parmeniani, Contra litteras Petiliani, De Baptismo contra Donatistas; 3) 401-405: período marcado por um incisivo avanço do partido de Donato no norte da África e consequente preocupação dos bispos católicos. Em 404 Agostinho participou de uma assembleia em Cartago na qual as autoridades episcopais da Igreja trabalharam em vista da construção de uma legislação anti-herética que auxiliasse na contenção dos cismáticos. O escrito antidonatista mais importante nestes anos foi sua Epistula ad Catholicos de secta Donastistarum; 4) 405-411: este intervalo inicia com a promulgação de uma severa lei antidonatista pelo imperador Honório. Ao longo destes sete anos Agostinho consolidou-se como a mais importante liderança católica envolvida nas discussões com os donatistas, esforçando-se, sobremaneira, em promover a paz e a comunhão com os mesmos; é preciso destacar seu empenho na organização de um concílio em Cartago no ano de 411; 5) 411-430: embora diversos especialistas na obra de Agostinho limitem sua abordagem da polêmica antidonatista ao ano de 411, Lamartine, amparado pela leitura de Langa, denota que a obsessão antidonatista de Agostinho mantevese acessa até sua morte, tendo ele produzido vários escritos relevantes nesta seara, como por exemplo, a epístola De correctione Donatistarum no ano de 417 (2021, p. 49-51).

Entretanto, seria incorreto mirar o supracitado período inicial no qual Agostinho envolve-se de modo efetivo na contenda com o partido de Donato e deduzir, por conta disso, que os pressupostos de sua eclesiologia são constituídos exclusivamente a partir deste recorte temporal específico. Embora a gênese de sua formulação objetiva se dê, de fato, nos escritos destes anos, tendo como motivação nevrálgica o espírito de contradição à mundividência donatista, é imprescindível que consideremos alguns fatores antecedentes. Adam Ployd endossa tal advertência ao afirmar que "para entender o pensamento antidonatista de Agostinho, precisamos olhar para aquelas fontes italianas, especialmente Ambrósio, e para aquela tradição latina mais ampla com a 
a partir da eclesiologia antidonatista de Agostinho de Hipona

qual Agostinho se engajou ao norte do Mediterrâneo" (2015, p. 12). Nessa recomendação, encontra-se um amparo para a tese de que o delineamento dos princípios fundamentais da eclesiologia agostiniana principia em um contexto cronologicamente anterior ao seu retorno ao continente africano. Ao mesmo tempo, ela nos permite reconhecer, na concepção agostiniana de Igreja, a inscrição dos caracteres de uma teologia transmarina. Ployd salienta que mesmo nos sermões da maturidade, como Enarrationes in Psalmos, Tractatus in Ioannis Evangelium e Tractatus in Epistolam Ioannis Ad Parthos, "o contexto histórico primário para a [...] leitura desses sermões [...] não são as fontes tradicionais do norte da África como Cipriano, Optato e Ticônio, embora sua influência não seja ignorada" (2015, p. 12). Mais adequado, no juízo de Ployd, é concentrar a análise em figuras vinculadas ou próximas à tradição de Niceia, como é o caso de Hilário de Poitiers e Ambrósio. Segundo Ployd, é nessa esteira que a teologia de Agostinho deve ser interpretada.

Sabe-se que Ambrósio, bispo de Milão, é, juntamente com Mônica, a mãe de Agostinho, a mais decisiva figura no processo de conversão ao cristianismo do futuro bispo de Hipona. Nos anos em que viveu e lecionou em Milão, Agostinho estabeleceu convivência e profícua amizade com Ambrósio. Segundo as Confissões, Agostinho se maravilhava com a habilidade retórica com que Ambrósio desenvolvia as suas pregações. Levando em conta que o próprio Agostinho se dedicava ao ensino da Retórica, e que do ponto de vista teológico havia sido um adepto do maniqueísmo por boa parte de sua juventude, é compreensível que o conteúdo dos sermões de Ambrósio não lhe fosse o principal objeto de observação. Assim diz Agostinho:

Acompanhava assiduamente suas conversas com o povo, não com a intenção que deveria ter, mas para averiguar se sua eloquência merecia a fama de que gozava, se era superior ou inferior à sua reputação. Suas palavras me prendiam a atenção. Mas, o conteúdo não me preocupava, até o desprezava (Conf. V, 13, 23).

Olhando para o processo de conversão vivenciado por Agostinho de modo retrospectivo, percebe-se pródigos vestígios da influência catequética, espiritual e teológica de Ambrósio. O hiponense lhe deve, no entanto, especial tributo no que toca aos fundamentos de sua eclesiologia. Segundo Paul C. V. Vuntarde, "é de Ambrósio que ele toma o método alegórico de entender as Escrituras, o que posteriormente teve um impacto profundo em seu encontro com os donatistas" (2012, p. 36). Os pressupostos basilares através dos 


\section{Tiago de Fraga Gomes \\ Darlan Paulo Lorenzetti}

quais o pensamento eclesiológico de Agostinho foi performado, encontram sua gênese já neste período que antecede, não somente seu batizado por Ambrósio em 387, mas até mesmo sua conversão em 386. Com efeito, podese dizer que há uma incisiva presença da pregação ambrosiana na edificação do ideário eclesiológico agostiniano. Segundo Vuntarde e Oort, nessa etapa propedêutica de sua formação eclesial, se dá a acepção daquelas ideias que doravante seriam as características definidoras de sua eclesiologia, as quais seriam duas: "a crença de Agostinho na autoridade da Igreja como mestra em questões de fé e prática; a autoridade da Palavra de Deus, que a Igreja católica interpreta corretamente para a fé e a prática" (2013, p. 4).

A disputa em torno da adequada interpretação dos conteúdos de fé inerentes à Escritura será um ponto crucial na polêmica antidonatista de Agostinho. A grande acusação do hiponense aos seus oponentes é de serem sectários também na leitura da Palavra, tomando em conta apenas alguns trechos específicos do texto e servindo-se de modo desonesto dos mesmos para fundamentarem seus argumentos. Na Epistula ad Catholicos de Secta Donatistarum, Agostinho expõe a fragilidade do separatismo do partido donatista, fazendo uso, justamente, da autoridade do texto sagrado: "Certamente prega outro Evangelho quem afirma que a Igreja desapareceu do resto do mundo e que permanece apenas na África, na seita de Donato. Portanto, que seja condenado; ou então me mostre isso nas Sagradas Escrituras e deixará de ser um condenado." (PL 43, Ep.ad.Cath 13, 32). Segundo Lamartine, Agostinho, ao ver-se envolvido nesse complexo certame teórico, sente-se desafiado a demonstrar as evidências racionais que, por consequência, tornam válida a crença na Igreja católica como única Igreja de Cristo e como único espaço em que se experiencia uma autêntica comunhão na fé e no amor. Para tanto, o bispo de Hipona ocupa-se com uma investigação de cunho essencialista, procurando rastrear a ontologia eclesial, distinguindo quatro qualidades fundamentais da Igreja: unidade, santidade, catolicidade e apostolicidade.

No tocante à controvérsia com os donatistas, a primeira e a terceira são especialmente caras pois coadunam-se sob a concepção de universalidade. Enfatiza-se quanto o donatismo em seu ethos dissidente representa uma investida contra o universalismo intrínseco à própria constituição ontológica do corpo eclesial. A causa motora da cizânia, pode, segundo Lamartine, ser identificada na "pretensão de formar uma Igreja composta somente por santos, uma santidade muito mais de âmbito eclesial do que moral ou personalístico" (2021, p. 81). Essa autopercepção revestida de puritanismo 
a partir da eclesiologia antidonatista de Agostinho de Hipona

remonta ao contexto das perseguições de Diocleciano no princípio do século IV e ao sentimento de repulsa aos lapsi ou traditores. O segregacionismo de Donato é oriundo da pretensão de edificar uma Ecclesia Martyrum onde somente tomam parte os puros e santos, herdeiros dos mártires. A reação de Agostinho a este equívoco é enérgica e efusiva. Agostinho não põe em questão a atribuição do epíteto santa à Igreja, haja visto que se Deus é santo, sua Igreja também o será. Sua divergência com os cismáticos se dá, de acordo com Lamartine, em virtude de sua oposição à "visão de que essa pureza assume uma formulação elitista e segregacionista, como pretendiam os donatistas" (2021, p. 82). Sendo assim, o erro dos cismáticos consistia precisamente no fato de que "insistiam na santidade como um esforço pessoal deles, parecendo não entender que, na verdade, é Cristo que, com sua graça, sana o homem ferido pelo pecado" (2021, p. 82). Para Agostinho, esta errônea percepção do donatismo fazia com que a seita caísse em flagrante contradição: ao julgarem como justificável o intuito de separarem-se do mundo devido à santidade e pureza, os donatistas perpetravam o pecado da presunção e da arrogância.

Entre os anos de 400 e 404 Agostinho dedicou-se à escrita de um tratado de refutação ao bispo Parmeniano, figura que havia sucedido Donato na sede episcopal cismática de Cartago, tendo desempenhado a função entrementes os anos de 362 e 391. Em Contra Epistulam Parmeniani, Agostinho tece uma repreensão à discórdia fomentada pelo donatismo:

Portanto, quem não quiser tomar assento na assembleia da falsidade, não se deixe inflar pela presunção do orgulho, com a pretensão de encontrar a assembleia dos justos separada da unidade do resto do mundo, porque isso é impossível. Os justos estão distribuídos por esta cidade universal que não pode ser escondida porque está assentada sobre uma montanha [...] e os justos que estão por toda esta cidade que se estende por todo o mundo, gemem e se entristecem pelas injustiças que são cometidas em seu meio. Que ninguém busque os justos em um grupo separado; em vez disso, busque a harmonia com eles e sofra em sua companhia, temporariamente misturado com os maus. [...] Ouça o apóstolo: "nossa cidadania está no céu". [...] Que ele viva com esta esperança, para um dia merecer a posse do que agora espera. Ainda não ressuscitamos como Cristo, nem estamos sentados com ele nas mansões celestes (PL 43, C.ep.Parm. III, 5, 27).

É possível observar que o Contra Epistulam Parmeniani, assim como outros escritos antidonatistas, além da finalidade apologética, tem um 


\section{Tiago de Fraga Gomes \\ Darlan Paulo Lorenzetti}

objetivo catequético. Ao responder a Parmeniano, Agostinho, na condição de bispo e pastor do rebanho, orienta os católicos à prática da tolerância com os pecadores, repreendendo, concomitantemente, aqueles que em sua soberba consideram-se santos ao ponto de desmembrarem-se da comunhão eclesial. Como bem recorda Juliana Marques Morais, "ao tolerarem os pecados alheios, os bons cristãos são coroados por Cristo, porque também esse foi tolerante. [...] Na pregação de Agostinho, os pecadores são servos, porque por meio de suas ações permitem que aqueles que vivem espiritualmente exercitem a tolerância" (2014, p. 63). A defesa agostiniana de uma Igreja mista, coabitada por virtuosos e pecadores, atinge o núcleo duro do engodo donatista. Agostinho nutria a percepção de que os cismáticos se equivocavam de modo retumbante quando julgavam que a acolhida, por parte da Igreja, àqueles que por alguma razão desviaram-se da santidade, produziria alguma espécie de mácula no corpo eclesial. Pelo contrário, para os seus membros, aquilo significava um exercício de purificação espiritual e aproximação, enquanto discípulos de Cristo, dos valores e sentimentos contidos no coração do Mestre, afinal "a comunhão com os pecadores não os tornava poluídos, mas sim os fortificava, os transformavam em cristãos melhores" (MORAIS, 2014, p. 63).

Agostinho, em Sermo 4, cuja datação é imprecisa, evoca a figura bíblica de Esaú para delinear o agir soberbo dos donatistas. Estes, a exemplo do filho de Isaac, preocupam-se em demasia com questões mundanas. A raiz do cisma encontra-se na empáfia e no exacerbado amor-próprio daqueles que "ao buscarem sua honra, perderam a paciência, encontraram a oportunidade e se separaram. Amavam muito a própria honra, concediam-na em demasia, enchiam-se de orgulho, não tinham tolerância, isto é, não tinham caridade" (PL 38, Serm. 4, 33). Agostinho afirma que os verdadeiros traditores não são os que em um eventual momento de fragilidade, face à perseguição, titubearam na fé, mas aqueles que, repletos de soberba, rompem a comunhão. Os únicos traditores são os seguidores de Donato. $\mathrm{Da}$ arrogância brota a divisão. A exemplo de Esaú eles passaram a "viver pela espada" (Gn 27, 40). A discórdia tornou-se força inexpugnável em seu interior. No mesmo sermão, poucas linhas adiante, Agostinho medita sobre tal condição:

Portanto, irmãos, aqueles que se separam são aqueles que vivem pela espada da divisão, aqueles que morrem pela espada e pela espada vivem. Mas é verdadeiro aquilo que disse o Senhor: "Aquele que lança mão da espada, pela espada morrerá $(M t 25,12)$. Vejam, irmãos meus, em quantos ramos 
eles dividiram, aqueles que se separaram da unidade. Vocês sabem a quantos partidos o partido de Donato deu origem (PL 38, Serm. 4, 34).

A existência de uma permixta Ecclesia é condição sine qua non da própria configuração ontológica da Igreja. Que o bem e o mal inevitavelmente convivam na comunidade eclesial depreende-se do fato de que há bons e maus cristãos. A Igreja é, em consequência disso, reflexo da condição humana perpassada pela tensão entre essas duas dimensões. Para Bavel, uma Igreja mista pensada desde suas várias particularidades, obriga todos a compreenderem que "a mistura do bem e do mal faz parte da Igreja em sua condição terrena, ainda que ela esteja orientada para a perfeição ontológica. Dessa maneira, a presença de pecadores no seio da Igreja pode ser 'justificada', e pode se tornar uma das características da verdadeira Igreja" (2018, p. 512). Tal compreensão tão mais será facilitada na medida em que não se incorra no erro donatista, se reduzindo a Igreja a uma realidade terrena e humana, na qual o critério definidor de sua santidade seja a virtude e o mérito de seus fiéis. Para Agostinho, o caminho da correta doutrina conduz a mente a perceber que a Igreja não pode ser entendida somente em sua realidade visível, terrena e histórica. As teses donatistas são claudicantes em diversos momentos por desconsiderarem aquela dimensão de invisibilidade pela qual a Igreja é constituída em seu ser. Ainda que a Igreja invisível não mantenha uma relação de pura identidade com a Igreja visível, a primeira está contida na segunda. Nesse sentido, José Luiz Illanes afirma que “a Igreja é uma comunidade concreta, empírica, visível, mas não se esgota no que manifesta a sua visibilidade, pois se refere a uma realidade transcendente e invisível: a comunicação efetiva da graça, a união vital com Cristo" (1995, p. 928).

Com efeito, Cristo é o fundamento e o sustentáculo da Igreja visível. A Igreja invisível - na qual habitam os santos e justos - goza da pax aeterna e da plena comunhão com Cristo, servindo de horizonte escatológico à Igreja terrena. Enquanto peregrina no mundo e na história, a Ecclesia qualis nunc est se projeta em direção à Ecclesia qualis tunc erit. Illanes pontua que "para a consciência cristã esta realidade invisível é, afinal, a realidade substantiva, o núcleo e a finalidade a que se refere a comunidade visível” (1995, p. 928). Ao intuir este movimento de afluência da Igreja terrena em direção à Igreja celeste, Agostinho propõe, em última análise, uma eclesiologia de comunhão. Cristo e a Igreja perfazem uma perfeita comunhão, o Christus totus, conforme a analogia paulina da Cabeça unida aos membros. Conforme se demonstrará 
na seção seguinte, esta formulação, a saber, da Igreja, Corpo de Cristo, ocupa, na eclesiologia de Agostinho um locus privilegiado.

\section{A Igreja, Corpo de Cristo: fundamentos de uma eclesiologia cristológica}

A compreensão agostiniana acerca da categoria de Ecclesia, ainda que contenha em seu âmago um conjunto de particularidades e complexidades a serem consideradas, mantém, de toda maneira, um sentido de coerência e harmonia no todo conceitual. De início, cabe ressaltar a prevalência, na eclesiologia de Agostinho de uma perspectiva dinâmica em detrimento de uma perspectiva estática. Apesar do bispo de Hipona não ser classificado strito sensu como aquilo que em filosofia contemporânea se denomina como um pensador "analítico" - alguém cujo fazer metodológico estrutura-se em razão de exercícios de distinção conceitual -, tal distinção constitui-se como elemento preponderante de sua eclesiologia. Bavel, ao discorrer acerca da semântica do termo Igreja na obra coletiva Augustine Through the Ages, elenca alguns níveis fundamentais de distinção: "Igreja terrena e Igreja celeste, a Igreja no espaço e no tempo e a Igreja como cidade de Deus, Reinado de Deus ou Reino dos céus; a Igreja peregrina e a Igreja triunfante, em sua plenitude escatológica; a Igreja-instituição e a Igreja Corpo de Cristo; a Igreja como entidade sociológica e a Igreja animada por Cristo e pelo Santo Espírito; a Igreja santa e a Igreja pecadora" (2018, p. 509). Naturalmente, o adequado esquadrinhamento das diversas peculiaridades inerentes a cada um dos recortes supracitados demandaria um processo de análise que no presente momento não se pode levar a cabo. Assim sendo, parece relevante esclarecer, de modo geral, sobre a ambiguidade da expressão estar na Igreja. Em um primeiro momento, refere-se à presença física das pessoas na instituição Igreja. Há, portanto, uma dimensão de exterioridade.

Concomitantemente, Agostinho salvaguarda como noção basilar de seu pensamento, a dimensão da interioridade, tratando-se, nas palavras de Bavel, de uma "participação interior no Corpo de Cristo pelo amor". A chamada Igreja visivel alocada nos limites do tempo e do espaço, é fortemente marcada pela dinâmica da processualidade em progressão. Trata-se de uma Igreja em marcha, em direção à consumação de uma realidade última, isto é, à realização do Reino de Deus em seu âmago. Este ethos processual se dá em virtude do horizonte escatológico inscrito no ser da Igreja. Em outros termos, embora a Igreja celeste/Igreja dos santos constitui-se como fonte doadora de sentido à 
a partir da eclesiologia antidonatista de Agostinho de Hipona

Igreja terrena/Igreja dos homens, ambas compõem a mesma unidade ontológica na qual edifica-se a Igreja Una. O conteúdo semântico dessa condição entendida como estar na Igreja não pode ser dissociado de outro eixo temático fundamental na obra de Agostinho: a coexistência das duas cidades: a Cidade de Deus, e a Cidade dos homens.

Ao contrário do que se poderia supor em uma leitura preliminar, não há equivalência ou identidade entre Cidade de Deus e Igreja celeste, bem como entre Cidade dos homens e Igreja terrestre. As duas cidades põem-se como comunidades de vontades, de maneira que na Igreja terrena ambas coexistem. A ação da graça, todavia, não está circunspecta à Igreja celeste, espiritual e triunfante, de modo que os cidadãos da Cidade de Deus peregrinam no aqui e no agora na forma da Igreja terrestre. Conforme afirma Agostinho no princípio do livro XV do De Civitate Dei: “quando por nascimentos e mortes as duas cidades começaram a desenvolver-se, primeiro nasceu o cidadão deste século, em segundo lugar nasceu o estrangeiro neste século e membro da Cidade de Deus, predestinado e eleito pela graça, peregrino cá em baixo pela graça e pela graça cidadão do Alto" (Civ. XV, 1). Enquanto observa-se um contraste irreconciliável no que diz respeito ao estatuto ontológico das duas cidades, por outro lado, percebe-se uma íntima e indissociável comunhão relacional entre a Igreja do alto e a Igreja terrestre.

Uma correta e adequada compreensão dos diversos contornos semânticos inerentes às noções de Igreja celeste e Igreja terrestre, passam por um preciso esquadrinhamento dos conceitos de Cidade de Deus e Cidade dos homens. Existe na eclesiologia de Agostinho um conjunto de sutilezas relativas ao seu particular encadeamento com as questões de caráter escatológico. Abstrair o modus segundo o qual se dá a gênese de uma ontologia relacional das duas Igrejas, celeste e terrestre, passa, fundamentalmente, por revisitar a clássica e emblemática distinção operada por Agostinho no livro XIV do De Civitate Dei:

Dois amores fizeram as duas cidades: o amor de si até ao desprezo de Deus - a terrestre; o amor de Deus até ao desprezo de si - a celeste. Aquela glorifica-se em si própria - esta no Senhor; aquela solicita dos homens a glória - a maior glória desta consiste em ter Deus como testemunha da sua consciência; aquela na sua glória levanta a cabeça - esta diz ao seu Deus: Tu és a minha glória, tu levantas a minha cabeça; aquela nos seus príncipes ou nas nações que subjuga, e dominada pela paixão de dominar - nesta servem mutuamente na caridade: os chefes dirigindo, os súditos obedecendo; aquela ama a sua própria força nos seus potentados - esta diz ao seu Deus: Amar- 


\section{Tiago de Fraga Gomes}

Darlan Paulo Lorenzetti

te-ei, Senhor, minha fortaleza; por isso, naquela, os sábios vivem como ao homem apraz ao procurarem os bens do corpo, ou da alma, ou dos dois [...] mas nesta só há uma sabedoria no homem: a piedade que presta ao verdadeiro Deus o culto que lhe é devido e que espera, como recompensa na sociedade dos santos (tanto dos homens como dos anjos), que Deus seja tudo em todos (Civ. XIV, 28).

A supracitada ausência de correspondência ontológica entre as duas cidades para com as duas Igrejas é referendada de maneira bastante contundente por Agostinho nessa passagem. Tanto a Cidade de Deus quanto a Cidade dos homens não são postas como instituições históricas, concretas e contingentes, mas sim, como entidades místicas. Como o princípio gerador de ambas é o amor, seja ele o amor de Deus ou o amor de si, ambas se constituem como comunidades de vontades, não encontrando, por isso, realização material na temporalidade e na espacialidade. Étienne Gilson, em sua Introdução ao estudo de Santo Agostinho, chama atenção para a concomitante tentação e para o consequente equívoco decorrente da equiparação substancial entre a Igreja e a Cidade de Deus: “a Igreja não é Cidade de Deus, pois essa cidade é a sociedade de todos os eleitos passados, presentes ou futuros. Ora, manifestadamente houve justos eleitos antes da constituição da Igreja do Cristo; há, agora, fora da Igreja e talvez entre os perseguidos, futuros eleitos" (2006, p. 343).

Esta mundividência reforça a significação mista da natureza da Igreja. Ao afirmar que as duas cidades coexistem no mundo, sendo muitas vezes indistinguíveis ao olhar da razão humana, Agostinho reforça sua crença na existência de uma Igreja que está configurada como permixta Ecclesia. Quando comparada ao segregacionismo donatista, a eclesiologia agostiniana parece, de fato, assumir premissas mais modestas quanto à pretensão de santidade e pureza dos membros do corpo eclesial. Nesse sentido, a universalidade, enquanto atributo essencial, é reafirmada: uma Igreja fidedigna à sua catolicidade jamais poderá ser a Igreja de uns poucos, que em sua arrogância, consideram-se os eleitos, e por isso, desde já, salvos. Gilson atenta para o fato de que "há na Igreja muitos homens que não estarão no número dos eleitos" (2006, p. 343). Como as duas cidades persistirão "misturadas aqui embaixo" até o juízo final, persistirá, até aquele dia, a indeterminação a respeito de quem sejam os verdadeiros eleitos. Somente aí, os cidadãos da Cidade de Deus serão, enfim, separados, dos cidadãos da Cidade do pecado. As palavras de Agostinho no De Civitate Dei são cristalinas quanto a este evento: 
a partir da eclesiologia antidonatista de Agostinho de Hipona

Muitos réprobos estão misturados com os justos e uns e outros se juntam como na grande rede do Evangelho; e neste mundo, como num mar, nas redes que a todos encerra, eles nadam à toa até ao momento em que, chegando à praia, os maus são separados dos bons, e nos bons, como em seu templo, Deus será tudo em todos (Civ. XVIII, 49).

A distinção da essencialidade metafísica daquilo que Gilson nomeia como "a sociedade divina dos eleitos e a sociedade diabólica dos reprovados" (2006, p. 344), poderá, enfim, ser percebida. A aceitação desta enfática tese agostiniana de contundente rejeição a qualquer relação de pura identidade entre Igreja e Cidade de Deus, poderia, prima facie, sugerir a existência de uma contradição fundamenta da eclesiologia do hiponense. No livro XX do Civitate Dei, Agostinho faz uma afirmação de caráter resoluto: "Portanto, agora, a Igreja tanto é o Reino de Cristo como o Reino dos Céus" (Civ. $\mathrm{XX}, 9)$. Como é possível que o autor afirme uma identidade que em outras passagens da mesma obra é tão decididamente recusada?

Nesse ponto, faz-se necessária estar sobremaneira atento a uma sutileza conceitual sem a qual a correta compreensão não terá lugar. Ao contrário do que muitos suporiam, da mesma maneira que a Igreja, também o chamado "Reino de Deus", não se identifica de maneira essencial com a Cidade de Deus. A Igreja enquanto Reino de Deus é o terreno no qual o joio cresce ao lado do trigo. Ambos só serão separados ao final. Se este reino não equivale substancialmente à cidade eterna dos santos, Agostinho está a falar "do reino em estado de guerra, no qual ainda se combate com o inimigo, no qual ora se resiste aos assaltos dos vícios, ora se domina sobre eles quando eles cedem, até se chegar àquele Reino de paz onde se reine sem inimigo" (Civ. XX, 9).

Contudo, é preciso salientar que mesmo que a Igreja e a Cidade de Deus não sejam, em sentido estrito, uma idêntica e única realidade, ambas estabelecem um profundo estado de comunhão, ao passo que a primeira recebe da segunda o seu horizonte teleológico, bem como o fundamento do seu existir. A ideia de peregrinação tão presente na obra de Agostinho, pode, quiçá, auxiliar na compreensão desta relação. No primeiro capítulo de suas Confissões, o autor denota esta teleologia incrustada no movimento daquele que, sendo estrangeiro nesse mundo, peregrina de volta para Deus, sua verdadeira morada e repouso: "Fizeste-nos para ti, e inquieto está o nosso coração, enquanto não repousa em ti" (Conf. I,1). 


\section{Tiago de Fraga Gomes}

Darlan Paulo Lorenzetti

Outrossim, também a Igreja peregrina dirige-se à Cidade de Deus. Conforme Gilson, "ela é a única sociedade humana que trabalha para construí-la; expressamente quista, fundada e assistida por Deus para recrutar os eleitos do Reino celeste" (2006, p. 345). Intrínseca a esta correlação entre os fins Igreja terrena e a consecução da Cidade celeste, há uma dimensão mediadora que é operada pela figura de Cristo. Esta condição de comunhão fundamental remete para uma metáfora - Igreja como Corpo de Cristo -, que pode ser considerada satisfatória no que toca à capacidade de exprimir tal condição do ser da Igreja. Para Victorino Capanaga, "o milagre da santidade e da universalidade da Igreja nos obriga a colocar nela um princípio superior. Por um duplo movimento dialético vamos da Igreja a Cristo e de Cristo à Igreja" (1969, p. 176). Em Agostinho, esta caracterização confere à sua eclesiologia um substancial caráter cristológico. Isso se dá, em primeiro lugar, pois a Igreja é concebida como espaço de salvação, exercício que por sua vez tem como fundamento a obra salvífica do próprio Cristo. Ainda conforme Bavel, "sem Cristo a Igreja perde seu significado. Cristo age nos sacramentos da Igreja: é Ele quem lhes dá vida" (2018, p. 510). Quando a Igreja administra, por exemplo, o sacramento do batismo, é, na realidade, o Cristo que batiza por meio do ministro.

Um segundo componente desta eclesiologia cristológica é afirmado através de uma espécie de ressignificação exegética. Agostinho toma a passagem do Evangelho de Mateus, "e sobre esta pedra construirei a minha Igreja" (Mt 16,18), vinculando o termo pedra não à pessoa de Pedro, mas sim, à fé em Cristo. Podese pensar a pedra como a fé de Pedro, isto é, da Igreja, na pessoa de Cristo. Há uma relação de anterioridade de Cristo em relação à fé apostólica, de forma que a primeira está posta como fundamento da segunda. A amálgama da Igreja enquanto Corpo é, pois, esta comunhão no seguimento à Jesus mediante a fé, a esperança e a caridade. Trata-se de uma "reunião ativa de uma nova humanidade em comunhão com Cristo” (BAVEL, 2018, p. 510). O verbo comungar, por sua vez, implica o sentido de participação na vida deste Cristo, ou seja, um itinerário de aproximação, e consequente imitação, por parte do discípulo, do ser e do agir do Mestre. "Participar da vida de Jesus significa: orar ao Pai como Ele orou; estar a serviço dos outros como Ele estava; ir com a mesma fé até os excluídos da sociedade e da religião; amar amigos e inimigos com seu amor" (BAVEL, 2018, p. 510). A Igreja, Corpo de Cristo, é chamada a ser sacramento, isto é, expressão visível desta comunhão. Agostinho é, sob este aspecto, herdeiro da teologia paulina no que se refere à absorção de um pressuposto fundamental 
a partir da eclesiologia antidonatista de Agostinho de Hipona

deflagrado por Paulo em sua Primeira Carta aos Coríntios: "Ora, vós sois o Corpo de Cristo, e cada pessoa entre vós, individualmente, é membro desse Corpo" (1Cor 12,26); assim como na Carta aos Colossenses: "Ele é a cabeça do Corpo, que é a Igreja; Ele é o princípio e o primogênito dentre os mortos, a fim de que em absolutamente tudo tenha a supremacia" $(C l 1,18)$. Joseph Ratzinger em O novo povo de Deus, demonstrou como a ideia de comunhão sugere a existência de um ordenamento de reciprocidade entre Cabeça e Corpo, entre Cristo e a Igreja. Ora, "para o bispo de Hipona significa que há um relacionamento com a Cabeça e o Corpo, com o Senhor glorioso e com a comunidade dos fiéis que, tomados em seu todo, formam o único Cristo" (RATZINGER, 2016, p. 55).

Pensar a eclesiologia agostiniana como uma eclesiologia de tal forma assentada em pressupostos cristológicos, impõe do ponto de vista conceitual, a incontornável tarefa de elucidação acerca do que venha a ser a compreensão de Agostinho acerca de Cristo. Tal conceito pode ser desdobrado e assimilado segundo tríplice caracterização: 1) O Cristo segundo sua divindade, isto é, enquanto Segunda Pessoa da Trindade, Verbo eterno de Deus; 2) O Cristo como homem e Deus encarnado, condição pela qual Ele, o Christo Mediator, opera a mediação entre divindade e humanidade; 3) Por fim, o totus Christus (Cristo total), "que compreende a Cabeça e o Corpo, do qual somos membros" (BAVEL, 2018, p. 510). Agostinho, notório devedor da teologia paulina como um todo, ao comprometer-se com o paradigma da Igreja, Corpo de Cristo, assume a condição de tributário do Apóstolo também em sua eclesiologia. A Igreja é, pois, a realidade na qual se verifica a continuidade da encarnação de Cristo, mesmo após sua morte, ressureição e ascensão aos Céus. Assim, o cristão em sua vida eclesial, atua como expressão sacramental do Cristo. Por meio da Igreja, enquanto ser, o humano e o divino compõem uma unidade performada não por identidade, mas por identificação. Por conseguinte, tal identificação resulta do ato de amor livre da divindade que quis unir-se à humanidade, tendo a Igreja como locus de manifestação. A adequada explanação de tal condição pode ser levada a cabo através da metáfora da Igreja como sponsa ou uxor Christi. Trata-se, com efeito, de uma unidade pessoal na qual dois entes, como o esposo e a esposa, formam comunhão.

Ao comentar, no tratado 47 do In Evangelium Ioannis Tractatus, o sentido da missão e do anúncio de Paulo entre os gentios, isto é, "as ovelhas que são de outro redil" e que serão, também elas, trazidas à comunhão, Agostinho ressalta a natureza servil intrínseca à figura do discípulo, aqui pensado como instrumento do Mestre. Assim diz o bispo 


\section{Tiago de Fraga Gomes \\ Darlan Paulo Lorenzetti}

de Hipona: "Portanto, mesmo quando é por instrumentalidade de Seus servos, é Ele e não outro que os traz. E ouça mais: 'Eles ouvirão a minha voz'. Veja que também aqui é Ele mesmo quem fala por Seus servos, e é a Sua voz que se ouve naqueles a quem Ele envia" (PL 35, Io. ev. tr. 47, 5). Quando o Corpo que é a Igreja fala, ora, suspira, deseja e exulta, é possível reconhecer aí a manifestação do Cristo que é sua Cabeça. Há, portanto, a conjugação de uma dualidade na unidade, de Cabeça e Corpo em comunhão. É mediante a ação profética e pastoral de seus discípulos, que o próprio Cristo dá testemunho de si. Dar e Ser testemunho vivo d'Ele é, pois, o eixo fundamental da missão apostólica da Igreja.

\section{Conclusão}

Após breve incursão pelos elementos pelo pensamento eclesiológico de Agostinho de Hipona, cabe rematar a reflexão recapitulando, ainda que sinteticamente, as ideias centrais trabalhadas na presente pesquisa. Conforme ressaltado no início, a eclesiologia agostiniana, assim com outros importantes núcleos temáticos da obra do hiponense, é desenvolvida segundo uma chave polemista. Nesse caso, ela está intimamente relacionada com a contenda intelectual travada entre Agostinho e os donatistas. Assim sendo, numa primeira seção, julgou-se oportuno reconstituir os fundamentos teológicos e doutrinais do donatismo, a fim de explicitar diversos fatores relativos ao contexto histórico, político e religioso no qual tal fenômeno foi gestado. Este enfoque epocal, teve como intuito reconstituir as condições e fatos nos quais o donatismo encontrou sua razãa de ser.

Da conjugação de todos estes aspectos, especialmente da pretensão de edificar uma Igreja onde somente os santos e os herdeiros dos mártires pudessem tomar parte, foi possível compreender o espírito cismático e puritano com o qual a seita de Donato revestia-se. Tal fato culminou em uma dissensão no âmago da Igreja no norte da África entre os séculos IV e $\mathrm{V}$ da era cristã. É em meio a estas complexidades que se inscreve a eclesiologia agostiniana. Contrariando os donatistas, o doutor de Hipona empenhou-se em constituir uma eclesiologia de comunhão através da noção de permixta Ecclesia. Nessa configuração, haveria uma Igreja mista e nela coexistiriam santos e pecadores, de maneira que a depuração ocorreria somente no juízo final. Para Agostinho, o puritanismo e o rigorismo cismático, além de causarem a cizânia no interior do Corpo eclesial, são uma injúria ao próprio Cristo. 
a partir da eclesiologia antidonatista de Agostinho de Hipona

Ao passo que esta eclesiologia de comunhão é estabelecida como um pressuposto fundamental a partir de um movimento reativo à heresia donatista, intentou-se, na última seção, situar um núcleo mais propositivo da reflexão agostiniana em termos de conteúdo e paradigma. Para tanto, desdobrou-se a noção de Igreja, Corpo de Cristo, ressaltando o radical estado de unidade ontológica firmado na Igreja entre o Cristo todo: Cabeça e membros. Nesse sentido, a vida e a missão da Igreja que peregrina no mundo e na história, representam a perenidade da Revelação de Cristo, haja vista que por meio dela, Cristo permanece visível aos homens e mulheres de todas as eras. Transcorridos praticamente dezesseis séculos desde a morte de Agostinho de Hipona, a genialidade, atualidade e relevância de sua obra persiste na atualidade. Sua eclesiologia nos oferece importantes luzes no que toca às sempre imprescindíveis reflexões sobre a universalidade da Igreja, bem como acerca da possibilidade de, a partir da diferença e da diversidade, produzir-se comunhão e unidade.

Desta reflexão, percebe-se algumas contribuições do pensamento de Agostinho para a fundamentação de uma eclesiologia de povo de Deus - conforme trata o Concílio Vaticano II, no capítulo dois da Lumen Gentium - onde convivem santos e pecadores, convivendo em comunhão, na diversidade de dons e carismas suscitados pelo Espírito Santo que edifica a Igreja como Corpo de Cristo. Essa dinâmica se embasa no mistério da Igreja - conforme o primeiro capítulo da Lumen Gentium. Além disso, o donatismo, enquanto dissensão interna na Igreja, expressa as crises que a Igreja enfrenta na vivência interior de sua comunhão, na história, além de invocar as tendências frequentes de um farisaísmo elitista e conservador que pretende criar uma elite eclesial, e de um pelagianismo e ativismo pastoral autorreferencial. Agostinho traz lições importantes para a Igreja atual: a humildade de compreender-se como uma Igreja frágil, chamada por Deus a uma missão sublime que se realiza na indigência de seus limites; e a decisão por empreender um caminho conjunto de comunbão, que tenha como referência o mistério de Cristo que chama os membros de seu Corpo à conversão pessoal e pastoral.

\section{Referências}

AUGUSTINUS HIPPONENSIS. A Cidade de Deus: Livro IX a XV. 2. ed. Lisboa: Fundação Calouste Gulbenkian, 2000, v. 2.

AUGUSTINUS HIPPONENSIS. Confissões. São Paulo, SP: Paulus, 1997. 
Darlan Paulo Lorenzetti

AUGUSTINUS HIPPONENSIS. Contra Gaudentium donatistarum episcopum libri duo: PL 43, 707-752.

AUGUSTINUS HIPPONENSIS. Contra Litteras Petiliani Donatistae Libri Tres: PL 43, 245-388.

AUGUSTINUS HIPPONENSIS. Contra Epistulam Parmeniani Libri Tres: PL 43, 33-108.

AUGUSTINUS HIPPONENSIS. De Haeresibus Liber Unus: PL 42, 21-50.

AUGUSTINUS HIPPONENSIS. Enarrationes in Psalmos: PL 36, 67-1028.

AUGUSTINUS HIPPONENSIS. Epistola 105. In: Epistolae: PL 33, 396-404.

AUGUSTINUS HIPPONENSIS. In Evangelium Ioannis Tractatus Centum Viginti Quatuor: PL 35, 1379-1970.

AUGUSTINUS HIPPONENSIS. Sermones: PL 38, 33-52; 1024-1026.

BAVEL, T. J. V. Igreja. In: FITZGERALD, Alan. Agostinho através dos tempos: uma enciclopédia. São Paulo, SP: Paulus, 2018.

CAPANAGA, V. Introducción General. In: Obras completas de San Agustín: introducción general y primeros escritos: vida de San Agustín, escrita por San Posidio. Introducción a los Diálogos. Soliloquios. De la vida feliz. Del orden. 4. ed. Madrid: BAC, 1969.

CLINGER, M. J. A Church Built on Charity: Augustine's Ecclesiology. Graduate Papers/ Theses, 2016. Disponível em: <https://digitalcommons.csbsju.edu/sot_papers/1918>. Acesso em: 19 Jul. 2021.

CONCÍlIO ECUMÊNICO VATICANO II. Constituição Dogmática Lumen Gentium: sobre a Igreja. 4. ed. São Paulo, SP: Paulus, 2007.

FREITAS, L. J. Estudo da construção do Ethos retórico Donatista e suas implicações no cristianismo africano do século IV e V. 2013. Dissertação (Mestrado em História Social), Faculdade de Filosofia, Letras e Ciências Humanas, Universidade de São Paulo, SP.

HOOVER, J. A. The Donatist Church in an Apocalyptic Age. Oxford; New York: Oxford University Press, 2018.

ILLANES, J. L. La eclesiología, presupuesto para la configuración de la historia de la Iglesia como disciplina científica. Scripta Theologica, v. 27, n. 3, p. 925-936, 1995.

LAMARTINE, C. A Igreja Corpo de Cristo: síntese da eclesiologia de Santo Agostinho. São Paulo, SP: Paulus, 2021.

LANGA, P. Introduccion gerenal. In: AGUSTÍN, San, Obispo de Hipona. Escritos antidonatistas. Madrid: BAC, 1988, v. 1., p. 3-155.

MARKUS, R. Donato/Donatismo. In: FITZGERALD, A. Agostinho através dos tempos: uma enciclopédia. São Paulo, SP: Paulus, 2018.

MORAIS, J. M. Levantes religiosos e combate ao diabo: concepções e práticas sociais no norte da África entre os séculos IV e V. 2014. Dissertação (Mestrado em História Social), Programa de Pós-Graduação em História Social, Universidade Estadual de Londrina, PR. 
a partir da eclesiologia antidonatista de Agostinho de Hipona

OPTATUS. Against the Donatists. Liverpool: Liverpool University Press, 1997.

PIRATELI, M. R. De Corretione Donatistarum Liber Unus: Igreja Universal e poder temporal na Carta 185 de Santo Agostinho. VIII Ciclo de Estudos Antigos e Medievais \& IX Jornada de Estudos Antigos e Medievais. 2010.

PLOYD, A. Augustine, the Trinity, and the Church: A Reading of the Anti-Donatist Sermons. Oxford; New York: Oxford University Press, 2015.

RATZINGER, J. O novo povo de Deus. São Paulo, SP: Molokai, 2016.

TILlEY, M. A. Literary and Legal Notes. In: Donatist Martyr Stories The Church in Conflict in Roman North Africa. Liverpool: Liverpool University Press, 1996.

TILLEY, M. A. Redefining Donatism: Moving Forward. Augustinian Studies, v. 42, n. 1, p. 21-32, 2011.

TORNAU, C. Saint Augustine. The Stanford Encyclopedia of Philosophy, 2020. Disponível em: <https://plato.stanford.edu/archives/sum2020/entries/augustine/>. Acesso em: 19 Jul. 2021.

VUNTARDE, P. C. V. Augustine's Ecclesiology And Its Development Between The Years 354-387ad., 2012.

VUNTARDE, P. C. V.; OORT, J. V. Augustine's ecclesiology and its development between 354 and 387 AD. Theological Studies, v.69, n. 1, p. 1-5, 2013.

Submetido em: 19-7-2021

Aceito em: 11-10-2021 